\title{
Family Disposition Related to Media Literacy \\ for Advertisements of Children's Snacks in the Media
}

\author{
FITRIA ANGELIQA \\ BILLY K. SARWONO \\ Universitas Indonesia, Indonesia
}

\begin{abstract}
The study on media literacy generally focuses on content about pornography and violence but does not pay as much attention to advertising. The practical implications of this study are the emergence of critical and analytical attitudes in accepting exposure to children's snack advertisements, especially those containing hazardous materials. This research has theoretical implications in filling the media literacy studies' gap that rarely aims at the content of children's snack advertisements. This study identifies parental-particularly mothers-disposition as part of an effort to literacy in the family. The role of parents is essential for the children's internalization of perspective. Parents can utilize children to understand the messages behind the snack advertisements. Applying the theory of habitus by Pierre Bourdieu, and the concept of street food as a product category of children snacks, and media literacy, this study takes a post-positivist paradigm. The data are obtained from a survey towards 285 parents in five cities in Indonesia (Jakarta, Bogor, Depok, Tangerang, Bekasi), and in-depth interviews were conducted with two mothers who have kids in elementary degree school. The results are the descriptions of dispositions given by the parents to their children relative to snack advertisements so that they can criticize and discuss what snacks should or should not be consumed by children. Furthermore, children have their own set of knowledge and set of attitudes about snacks that can cause health problems.
\end{abstract}

Keywords: Advertisements, children's snacks, disposition, family, media literacy.

\section{INTRODUCTION}

How children grow and develop is strongly determined by to what extent society pays attention to their needs, particularly in whether children are fed with tasty, nutritious food. The food intake of a child may be the most important thing for their development. According to the findings of the Indonesian National Agency of Drug and Food Control (BPOM), $48 \%$ of snacks consumed by children at school within the previous five years (2006-2010) do not meet food safety requirements, because they contain dangerous chemicals. Food additives (BTP) in children's snacks at schools often exceed microbiological safety and contamination limits. Samples of schoolchildren's snacks obtained in six provincial capitals (Jakarta, Serang, Bandung, Semarang, Yogyakarta, and Surabaya) have found that 72.08 percent contain dangerous substances. Moreover, according to extraordinary event data, compiled by the Directorate of Food Safety Surveillance and Counseling-BPOM RI from all of the branch offices in Indonesia between 2008 and 2010, 17.26-25.15 percent of cases of food poisoning occur among elementary school students (Badan Intelejen Negara, 2012).

In certain regions, children's snacks were found not to meet standards. Among which are ice cream products; tests of such products conducted by BPOM in 2013 showed an astonishing result $58.24 \%$ of ice cream products sold at school did not meet government health standards. One factor leading to this result was the poor microbiological quality of ice cream products (Syatria, 2013). More than $85 \%$ of the tested school snacks did not pass a 
health sanitation test conducted by the public health office of DI Yogyakarta and BPOM. Dye and other harmful substances endangering children's health are still found in most of the snacks sold at school (KOMPAS, 2010). Each of these unhealthy snacks contains at least oneor more-dangerous chemicals, such as formalin, borax, rhodamine, and metanil yellow, all of which are carcinogenic. Borax and formalin are usually used as preservatives, whereas rhodamine and metanil yellow are used as dyes (Prasetya, 2010). Sampling conducted by BPOM in 2011 found that these four banned chemicals appeared in different snacks offered at school.

Children's snacks are widely advertised on television and they are attached to children's television programs. According to Nielsen (AGB Nielsen, 2010), children predominate in the Indonesian television audience. Unfortunately, children's shows on television are relatively low in number (2.7-4.5\%), relative to the total number of shows (Yudono, 2013), and the quality index levels of these programs are also low, reaching only $3.03 \%$ on average (Komisi Penyiaran Indonesia, 2015). The low index of children's television programs is similar to the snack products advertised in it. The advertisements on television are produced to match these values.

In the normative term, the creation and presentation of advertising content must conform to ethical statements to which the advertisers are morally bound. The third point of the Indonesian Advertisement Ethics, mention that an advertisement whose target audience is children must follow some rules (P3I, 2015). First, children cannot be used to promote products that are inappropriate for them without being accompanied by adults. Second, advertisements cannot show children in a dangerous, misleading, or inappropriate scene. Third, advertisements cannot show children as the promoters of products that are not suitable for children. Fourth, advertisements cannot show scenes exploiting children's ability to pester adults to allow them to give in to their request to obtain the advertised products.

Such ethics regulate how advertisements for children must be presented. The children's development and their inability to decide for themselves should be the first things to consider. Besides two aspects of Advertisement Ethics are noted above-in the context of children's snack products - the hypertextual and hyperbolical aspects in advertisements can increase the harmful effects of dangerous substances or the lack of nutrition in snacks (Lister, Dovey, Giddings, Grant, \& Kelly, 2003, pp. 16-18). The amount of dye, flavoring, preservative, sugar, calorie, and saturated fat cannot be explained and given in the advertisements because of the inability of the target audience to decrypt the message. Children's snack advertisements emphasize colors, funny shapes, and the freshness and deliciousness of drinks or food (http://wapwon.info, n.d.) rather than the effects on one's health or information on nutritional contents. Nevertheless, the lack of nutrients in children's snacks matches the price (http://www.snspoint.com, 2016) that is adjusted to match children's pocket money.

Apprehension relative to the impact of television advertisements on children's behavior is understandable because there are sufficient numbers of studies demonstrating the influence that media has on the attitudes and practices of the children. There are also many studies showing that the effects of the media can be minimized through message filtering. Because basically, (adult) consumers are aware of the commercial driven-purpose of these advertisements (Huat, 2019). There are, in general, few advertisements that effectively attract the consumer's attention (Sutherland \& Sylvester, 2005, p. 143), meaning that not all advertising messages easily influence their targets. In other words, the advertisements do not necessarily reach the consumer directly, so long as agents exist who construct different realities concerning the target consumer. It can be assumed that the effects of the media on 
children depend on the role played by individuals who matter to the children. It means that parents tare very much needed in the part of agents who can minimize the impulsive urges of children to consume unhealthy snacks or snacks with low amounts of nutrition -caused by the intense exposure of television advertisements.

Advertising strategies that focus on persuasion that works emotionally are the most significant factor promoting children adopting poor consumption patterns (Kristanto, 2012), considering that children cannot yet comprehend the problems and contexts before them. They next impulsively ask for what they have just seen on television. Moreover, it is not uncommon for snacks to offer other benefits, such as bonuses or gimmicks, that make them more attractive to innocent children. Hence to develop the ability to comprehend advertising, there is nothing more important than a synergy developed between family and school.

Media literacy had grown since the 1970s, when the term social construction was born, which made the impact of media comprehensible. The media have great significance because of their ability to construct reality. It has a twofold origin: (1) the media practices social construction through the framing of reality, in a predictable and patterned way, and (2) the audience construct themselves on the frame of social reality presented by the media and its environment. This concept promotes the awareness of the audience's ability to freely choose media content (McQuail, 2010).

In the context of advertisements for children's snacks, media literacy is especially critical. Advertisements for children's snack emphasize on frivolous that impress children's attention, rather than the effects on health or nutrient contents. Media literacy for children requires that the people surrounding the children, mainly the parents, teachers and school, and peer groups, play an active role. The impulsive urge to consume unhealthy snacks or snacks with low nutrition that tare advertised on television can be filtered or even strengthened by the disposition of those actors. Critique, analysis, and discussion of media literacy must at least begin from the most straightforward aspect, namely, knowledge of the advertised product. Knowledge of the dangerous substance and nutrient content can shape the ability of the children to determine what is right and what is not right to eat. The proposed research question is, how does the family influence children's disposition to children's snacks, and how does children practice media literacy in watching children's snack ads?

\section{CONCEPTUAL FRAMEWORKS}

In this section, essential concepts forming the foundation of the dispositional activities in the family regarding the number of harmful substances in children's snacks will be elaborated.

\section{a. Habitus as Disposition}

Habitus is a disposition formed over a long period, a structure reflected in various unconscious actions; it has been called the giver of dispositions. On other occasions, related to stimuli, habitus operates as conscientious practice. It is even found to be full of determination, which is still in line with previous experience in the face of similar stimuli. Habitus then gives guidance concerning what can or cannot be done or said where an individual faces a similar context (Bourdieu, 1980, p. 53).

As a form of disposition, habitus can be passed from one group to another, one individual to a second individual, or from one generation to the next. Habitus inherited naturally. It could potentially shape an individual's permanent character. Habitus grants a path for an individual to take, becoming a practical conscience, telling how and when to 
behave, and the individual acting refers to the context he/she is facing. The skill of creating habitus cannot be obtained instantly. There are historical traces stored in an individual's stock of knowledge that can perhaps be modified by contexts occurring to them. Habitus even enables individuals to forecast what action should be taken next, according to those experiences (Bourdieu, 1980, pp. 53-55).

Therefore, habitus is formed both generatively and socially, simultaneously. When it is formed generatively, dispositions are obtained through experiences that differ in space and time. This disposition is also adjusted according to one's position and opportunities. Disposition is a product of the internalization of inevitable objectives because it is the way things have to be. The transfer of disposition is also accompanied by the giving of understanding on how the strategies should be adjusted according to the situation that one faces in the future (Bourdieu, 2011, pp. 15-16).

In consequence, habitus also gives an individual the sensitivity and ability to respond to various events in daily life. Disposition is potentially permanent, which unconsciously offers orientation to their actions and inclinations. Habitus guides the individual in their games and prepares a set of proper actions, termed practical sensitivity (le sens pratique). In this way, habitus becomes a state of mind, a state of the body, and a state of being (Bourdieu, 1983, p. 13).

As a state of one's body, habitus can be embodied and become a permanent disposition that is hard to change, termed hexis (Bourdieu, 1983, p. 13, 1980). The body is so crucial because durable dispositions need the body not only to absorb but also to implement the experience. Hexis is an organization wherein the body interacts with its worldly experience. Uniquely, the embodied habitus can be passed on to other persons, regenerated, and even become a characteristic of a group.

As noted previously, habitus can never be dissociated from the concept of field, as all the desired positions as well as practices to maintain them exist in a specific field. This field is social life, which has its own organizing rules, manages the unity of positions, and promotes practices associated with the positions. The social field provides the opportunity to obtain existing and other positions. Bourdieu states that action in the field is not the static reflection of positions that previously existed but is the result of various agreements to obtain positions (Bourdieu, 2007; Calhoun, Gerteis, Moody, Pfaff, \& Virk, 2009, p. 262). Bourdieu asserts that there is a struggle in each field to obtain domination. Here, we must discuss the capital. This capital can be economic, social, cultural, and symbolic.

From the above, it can be seen that habitus is, in fact, a result of the internalization of dispositions from various contexts, consisting of values, culture, ideology, et cetera, which eventually determine an individual's personality, behavior, thinking, and mentality. Thus, habitus is the result of learning, which keeps growing as one enters more fields, using a different habitus for each. The ownership of a certain amount of capital also determines what habitus is more dominant within an individual. The field connects an individual's habitus and capital, making it a relevant social practice.

The family is a child's first agent of socialization, for its early life is centered around his or her family. Children gradually learn the shape of the environment created by society, and what they absorb is quite likely to be influenced by how their parents socialize them. Slowly, their families teach children their social positions, not only their positions on earth but also their positions in society, according to their race, ethnic group, religion, and from what class they originate (Stewart, 1981, p. 133). By one's family, one is taught various things, the most important of which are learning how to communicate with one's peers and building language 
skills. The values learned by children from their families are usually kept alive until they become adults (Persell, 1984, p. 132). It is natural then that the origin of the initial disposition of an individual is to be found in the family. The disposition of the family is known as the original habitus because it gives many traces of embodiments and thinking stored permanently within the individual.

\section{b. Street Food}

The health minister's decree on the hygiene requirements for food sanitation (http://dinkessulsel.go.id) categorized street food as food and drinks processed by food craftsmen at stalls and served as ready-to-eat food to be sold to the public. Winarno and Allain (1986) define street food as a wide range of ready-to-eat food and beverages sold and sometimes prepared in public places, notably on streets.

It is difficult to determine whether food products contain dangerous chemicals, mainly when the doses are small. However, when the doses of such chemicals are rather high, we can recognize them from the visual appearance of the snacks - the chemicals in food that are categorized as dangerous fall into four categories - first, hazardous preservatives, such as formalin and benzoate (if used excessively). Second, dangerous dyes, such as the red dye of rhodamine-B and the yellow dye of metanil yellow. Third, excessive artificial sweeteners, such as natrium (sodium), saccharin, cyclamate, aspartame, and sorbitol, and fourth dangerous meatball plasticizers, such as borax.

There are many adverse effects of the contamination of dangerous chemicals used as food ingredients. Some common ones include poisoning, from ordinary symptoms to death; cancer, in cervical, lung, breast, prostate, and brain; convulsions, from subtle spasms to severe seizures; circulatory collapse, such as the disruption of the heart, brain, reproductive system, and endocrine functions; other symptoms, such as vomiting, mucus in stool, depression, and neurological disorders; and severe symptoms, such as blood in urine, vomiting blood, and seizures.

\section{c. Media Literacy and Health Literacy as Dynamic Process}

Media literacy is traditionally defined as being able to determine the meaning intended by the creator of the media content (Kress, 2003, p. 17). The study of this concept has grown together with the development of television content that is thought to be significantly altering behavior in society. Nonetheless, on the simpler terms that were developed in reaction to the growth of communication technology, media literacy is also defined as the skill of reading media texts (Baran, 2013, p. 21). It is an ability to choose, understand (the format, style, industry, production, and media impact), analyze, question, or adequately respond to the media content that is consumed. Media literacy is, therefore, a kind of reflective appraisal by an individual of media content (Silverblatt, Miller, Smith, \& Brown, 2014, p. 4).

Media literacy means using media intelligently. The audience must become active in accessing, choosing, evaluating, and re-communicating the messages they get from the media to other people. The objective is to make society more critical in consuming media, reviewing the broader agenda of the media, and then, on the other hand, appreciating the positive values of the content. Moreover, media literacy can hopefully overcome problems of the perceptual disputes that occur as people consume media content (UMY, 2015). Media literacy requires a community that can actively discuss content. Conversely, media literacy also needs 
the industry to produce meaningful and high-quality content (and products) (Silverblatt, Miller, Smith, \& Brown, 2014). It shows that media literacy requires learning to allow an individual's skill to reflect on media contents to be developed.

It is thus clear that media literacy is not merely a concept of the understanding but also related to one's attitude and the actions an individual can take against media contents. Individuals are encouraged to recognize, know, like/dislike, and act against various aspects of media contents and their effect on an individual. The skill certainly demands habituation and everlasting learning, such that an individual only consumes fruitful content and channels. Thus, media literacy yields the following benefits not only for users of media but also for the industry.

In the context of snack product advertisements, media literacy has high connectivity with health literacy. Both of those terminologies have the same vision: to enhance individual awareness of dangerous symptoms contained in many kinds of contents, programs, or products. The mass media present both complex and overly simplistic messages about health. They can improve health literacy or reduce health literacy. Mass media can educate individuals about healthy behavior or establish powerful role models for harmful behavior. Thus, for health practitioners and communicators concerned about improving health through improving health literacy, a basic familiarity and understanding of the mass media is an absolute must. Health literacy consists of a dynamic group of productive and generative skills a person calls on when facing new situations. This generativity is what makes health literacy sustainable and enables health-literate people to make more informed decisions, benefit from healthier choices, and have degrees of independence from experts and knowledge intermediaries. When people have a reasonable degree of health literacy, they know how to seek out, access, judge, and use information about their health. They also are better prepared to know what they can discard as outdated, unreliable, or simply wrong (Zarcadoolas, Pleasant, \& Greer, 2006, p. 49; 93).

\section{d. Thinking framework}

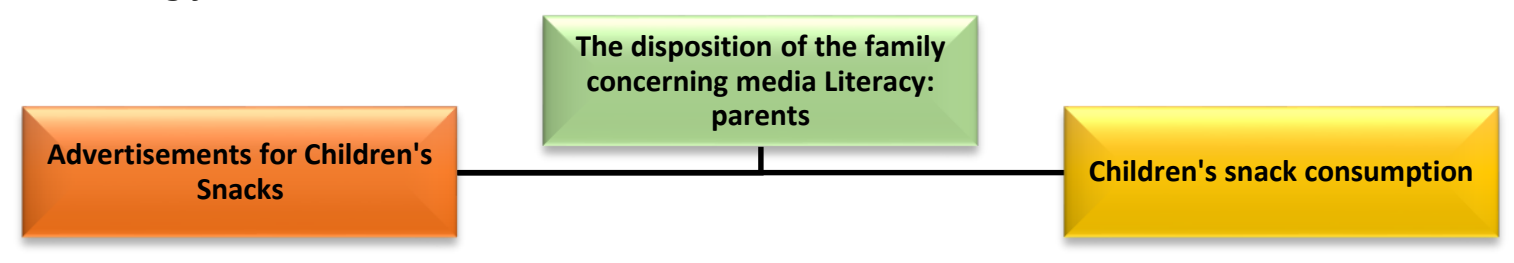

Source: created by the author, 2016

\section{METHOD}

The paradigm of this study was post-positivist, using a mixed-method of quantitative and qualitative approach. Quantification was utilized to measure the literacy of the parents about the message of the advertisements for children's snacks containing harmful substances. The qualitative method was used to explain the quantitative data, which were obtained first, particularly in describing how the parents are the source of their children's disposition regarding the dangerous chemicals contained in snacks or street food and drinks.

A survey was used to collect the primary quantitative data for this research. The analytical and observational units of this research are the individuals, namely, the audience exposed to the children's snack ads, especially parents with children who consume children's snacks. Specifically, the target population of this study was the parents of children who go to various elementary schools in Bekasi. Elementary schools were chosen as the research 
environment because, according to the data KLBs of food poisoning in Indonesia collected by BPOM RI from 2008 to 2010, most cases occurred in elementary school students (Badan Intelijen Negara, 2012). The samples of this research were 285 parents residing in Jakarta, Bogor, Depok, Tangerang, and Bekasi, selected through a non-probability technique to fulfill quota sampling. The number of samples was determined relative to these considerations: the accessibility factor (the informants who are the easiest to reach), time limitations, human resources, and the research budget.

In its quantitative approach, this study only analyzed one primary variable, namely, media literacy, which is rated according to an ordinal scale and quantified in the SPSS software program. Conceptually, media literacy is the skill to read/understand media content, which is a fruitful skill that generates, in turn, various skills of reflecting on the influence of media contents on oneself. Media literacy is related to knowledge, understanding, and attitudes about the contents of dangerous substance, which includes dimensions of (1) being willing to understand; (2) giving attention; (3) ability to filter; (4) being willing to discuss; and (5) being willing to limit the consumption of dangerous substances. Furthermore, hazardous substances are defined conceptually as different kinds of chemicals used as additions to food (Dono, 2012).

Moreover, the qualitative research was conducted through in-depth interviews of two mothers who work as lecturers. Both the informants were chosen as different in the SSE character from the survey sample because the researchers were skeptical of the quantitative research results that only provided general data on literacy and wanted to find out more from another perspective on the literacy about children's snack advertisements in different groups.

\section{ANALYSIS AND INTERPRETATION OF DATA}

The data were obtained by giving a questionnaire to 285 parents of students of Elementary Schools in five areas near Jakarta. The result of this research was also supported or confirmed by in-depth interviews with two parents of children who are still in elementary schools. The first informant (RK) is 42 years old and is the single parent of one child who goes to a private elementary school in South Jakarta. Meanwhile, the second informant (NP, 35 years old) is the mother of two children from Depok, West Java. RK and NP are both working mothers and come from the middle class; they are giving serious attention to their children's food health.

\section{a. Respondent's Characteristics and Children's Snack Consumption Patterns}

Quantitative analysis was used to calculate the sum of the characteristic data distribution of the respondents (the parents) and whether they understand the habits and behavior of their children in consuming snacks, especially those that contain dangerous substances (B2). As well as the form of the reception of children's snack ads from various sources of information. The finding shows that the plurality of respondents has a medium monthly income, from around $\mathrm{Rp} \mathrm{3,000,000} \mathrm{to} \mathrm{more} \mathrm{than} \mathrm{Rp} \mathrm{4,000,000} \mathrm{(72.6 \% ).} \mathrm{Most} \mathrm{of} \mathrm{the} \mathrm{parents} \mathrm{live} \mathrm{in} \mathrm{Jakarta}$ (40.7\%), and their homes are located less than $5 \mathrm{~km}$ from school (49.1\%).

Most respondents answered that their children had meals prepared at home for them to bring to school (62.4\%). For another group of respondents, their children did not have meals prepared at home (around 30\%). It implies that almost half of the respondents bought meals at stalls outside and packed them for their children. Bubur Ayam, meatballs, gorengan, Kue, martabak telur, mie goreng, nasi goreng, nasi uduk, and bread make up the possible alternatives for parents who purchase their children's school meals. Some respondents gave 
their children pocket money to buy food or drinks. Most mothers supplied their children with drinks from home. Furthermore, the data show that the mothers were the only ones who prepare meals and drinks for the children.

It was reinforced by the statement of RK, who stated that she always supplied her child with a complete lunch box (rice, side dishes, vegetables, and drinking water) so that her child's hygiene could be ensured. RK additionally ordered food from a catering service that produced meals with a controlled amount of salt and sugar and without MSG, to supply a healthy lunch for her children. The same reason was also given by NP, who never gives pocket money to her children and is more inclined to create a complete lunch meal (bread/spaghetti/rice and side dishes, milk, biscuits, and water) and even snacks. For the two informants, the hurry in the morning to prepare their children's meal was not comparable with the consequences for their children if they allowed them to consume school canteen snacks or food sold outside the school.

In the in-depth interviews, the two informants also explained the snacking habits of their children, which are, in general, more likely to be controlled by parents. RK only allowed her child to have refrigerated drinks - such as bottled tea-once a week. She also gave her child pocket money, Rp 10,000 per day, which was intended to buy needed items or call home if there is something urgent. Most of the time, her child did not use the money, instead of saving it to buy other things. Generally, NP did not give her children pocket money at all, because, as the school does not have a cafeteria, equipping children with a meal to take in is compulsory for the parents of all the children attending it. Outside school hours, neither RK nor NP allowed their children to eat snacks containing MSG, such as chiki. RK worried that consuming those kinds of food would trigger her child's allergy, whereas NP was afraid that her children would contract a sore throat. Unfortunately, obedience to all rules was lost when the children are with their extended family (at their grandparents' home, for instance). NP said the following:

"... Sometimes I buy them such things, but they never buy them themselves, especially when they are in my hometown, where their grandparents own a restaurant, so they have those kinds of snacks, and the snacks they have are 'chiki,' 'taro' ... all they have to do is ask. If they are there, oh my god.... You know when they are with their grandparents, it is hard to forbid them, but they know, however. Since my youngest has an allergy, it is easy... his tonsil is easily triggered ... It is easy to trigger after eating those kinds of snacks. His breath gets smelly, and the doctor said that when the breath is smelly, it means that the inflammation is happening, it is swollen. The eldest is different, and says, "Oh, it is so salty." She thinks the chikis are too salty because she is used to having home meals".

\section{b. Data on Information Sources for Children's Snacks}

All parents still chose television as the source of information concerning children's snacks. Furthermore, the other information sources to which the parents referred were nearby friends/neighbors (40.7\%), and the school cafeteria's waitress (70.8\%). Meanwhile, the two informants also obtained information from cable TV and the internet, which can also be accessed by the children. Because of the lack of advertisements on cable TV, the tendency for both parents and children to be exposed to children's snack advertisements was minimized. 
Additionally, the children browsed the internet to see animals, their favorite things. However, when they were bored, children sometimes watched popular TV shows, often The Voice of Children, airing on a paid channel. While watching this show, children are exposed to children's snack advertisements, such as the advertisements for Paddle Pop ice cream and Super wafers. After watching, the children of the informants then usually asked whether they could have these snacks. It means that instead of being affected by the advertisements, children rather follow the path that they are disposed to by them - the decision whether or not they are allowed to have the product depended on their parent's consent.

The informant interview brought interesting data to light concerning the source of information. Nothing that they were brought up in the county and that most of their extended families still live there (RK was a descendant of people from Bogor-Ambon; NP's family came from Ciamis). Both informants were used to consuming home food because their parents forbade them to snack outside. It was not until she moved to Jakarta as an adult that NP contracted typhus: her love for street food caused this illness and made her gain weight. Worrying that their children would experience the same illness, she limited their snack consumption. She even sorted the birthday packages her children brought from school to determine which could or could not be consumed. Moreover, the history of obesity in her husband's family, which could trigger many illnesses, was a concern for her in limiting her children's snacks.

On the other hand, for RK, the fact that most of her family were larger and had a history of heart disease was a firm reason for her to limit the consumption of snacks of her only child, supplying him with various healthy foods. Her child's character, a picky eater, has made it easier for her to give food that is following her child's appetite. Uniquely, because he is used to being limited in snack consumption, the child is not interested in the snacks sold in front of his schools, such as noodles, es limun, and other coveted foods. When RK wanted to take her child to a fast-food restaurant, her child refused the offer, because the foods there were unhealthy.

It shows that disposition is generative and inherited from one generation to the other. Similarities of disposition occur because similar experiences occur in different generations or other contexts. Experiencing illness or seeing family members who were dead because of digestion or weight problems creates disposition in the family circle. RK showed how the obedience of her children was embodied, becoming a permanent habitus to refuse fast foods that are high in calories and salt. Eventually, the disposition of the family generates a habitus in the form of a child's social skills in facing various contexts in their social life.

\section{c. Average Values for Media Literacy}

An index was created to calculate average scores on a scale ranging from 1 (strongly disagree) to 5 (strongly agree). The media literacy of the respondents was measured based on the average scores, categorized into 5 (five) overall values, namely, very high, high, moderate, low, and very low. Based on the categorization above, the threshold for media literacy or standard for skill index could be determined: the literacy of a respondent with an average score between 4.00 and 5.00 was categorized as high or very high. From the findings, the average score of the parents' media literacy was low (3.3), implying that the parents did not have functional media literacy. 


\section{DISCUSSION}

The quantitative portion of this study showed the role of the family in giving an original disposition for children's understanding of street snacks. However, the role of the mass media, such as television, may be more significant than that of the school canteen, which is to be inferred from the data found regarding sources of information. Moreover, the parents unanimously stated that television advertisements are the primary source of information concerning children's snacks. Furthermore, the mass media act as an impersonal communication media, presented to a vast audience, in the form of print media, electronic media, or television media. Long before they learn to read, watching television is routine for children; even more, they spend more time in front of the television than at school. Ownership of cultural and economic capital, indexed to the level of education and monthly income, relates to how parents perceive the media literacy concerning advertisements for children's snacks in the media. The respondents stated that television was their primary source of information, choosing the mass market, and free media. Two informants' answers differed from this pattern, and both were working mothers possessing a high level of education. Cable TV and YouTube, which needs an internet connection, were alternatives for their children's entertainment. Bourdieu's concept of cultural capital determines the taste of individuals in social practice. The choice of visual entertainment (art) is one of them.

However, the family is the first and primary source of disposition for each child. Within the family, children gradually learn the shape of the environment created by society. Togetherness and the relationship between parents and children were conducted continuously (Triwardhani \& Chaerowati, 2019) as initial inter-subjectivity relationship for individual. Hence various values acquired by the children from their families will be carried with them until they are adults, including values relating to receiving and filtering media content. The in-depth interviews illustrated this. Childhood experience and traumatic experience of illness or even death of other family members formed the living trace, leaving scars, which cannot be erased from memory. For the early disposition toward health in the family, mothers play an important role as the primary perpetrator, mainly when their children are still in childhood. Mothers give much affection and make clear what food and drink can be consumed.

All of those behaviors are not only based on concern for their health but also and primarily because of their experiences, which formed their perspective on mind and body, over time. That experience forces them to transfer a generative disposition on food and drink to their children, for health reasons. Besides forbidding them to their children, mothers consistently avoid consuming foods and drinks containing dangerous substances. This is where the transfer of disposition can potentially occur. Implicit habitus affects children most during their childhoods. This implication simultaneously takes the original form of the state of mind and the state of the body. As a result, the children precisely mimic the actions and thinking of their parents.

Events experienced by the parents being transferred to their children's behavior is in accordance with Bourdieu's idea of the "body as a historical site" (Bourdieu, 1983, p. 13), which captures the ability of the body to absorb worldly experience and remember it as a part of its stock of knowledge. According to Bourdieu, the body can run on autopilot because of the automatization of habits (Bourdieu, 1980). This illustrates how habitus as the disposition of historical products is intertwined with both mental and physical processes, which happen with or without intention within oneself. Uniquely, besides possessing habits, on various 
occasions, individuals can automatically adjust to every context they face, referring to historical experience. This is clearly illustrated in how RK's child refuses to eat fast food.

However, the media are not the only cause leading to questionable behavior by an individual. Especially in modern society, which is becoming a postmodernist society, togetherness in communities becomes very important, in that the boundaries between individuals in public and private contexts are hard to distinguish (Arnett, 2007, pp. 70-71). The agents of socialization, mainly the family, have the potential to shape specific patterns that influence thinking and action. Therefore, one's choice of media content is often not a private one but a construction built in one's communities. A person's closeness to his or her family or other agents of socialization may lead him or her to only choose content that conforms to the community that shelters that individual. The leading community surrounding children is undoubtedly made up of their parents.

Media literacy is a deconstructive effort that can be conducted by an individual as he or she is consuming media. Developing media literacy bears fruit not only in media skills but also will in the realization that media contents always come with intention. This has either economic or political interests and can influence many aspects of culture within society. As they are run by the industry, the content that media supply must always have economic value. Becoming suspicious of the constructive interest of the owner of the media attached to content is the first step to developing literacy. Unfortunately, only rarely do individuals realize such problems without being helped by others. A child's parents, school environment, and friends will determine whether true literacy is being created or remains within the domain of discourse. The disposition of experience occurring to the parents can be transferred through the habit of discussing the dangerous substances contained in snacks and their effects when consumed over the long term. This habit always grows along with the understanding of the children concerning the kinds and effects of harmful chemicals, based on how their cognitive aspect develops.

\section{CONCLUSION}

This study shows that mothers remain unable to act as agents of literacy, especially for elementary school students. The media, for their part, mainly television, are at the forefront of sources of information for both parents and children on children's snacks, followed by the peer group and close family. Nevertheless, families can create boundaries through daily disposition or social practices taught to children no matter how simple, including how to choose snacks. Here the role of parents as the principal-agent of the disposition of media literacy to their children is needed. The intense interaction between parents and children significantly affects the actions of anticipation to prevent the harmful effects of snacks containing dangerous chemicals. It is no wonder that a lack of media literacy skills among the parents affects children's patterns or behaviors of snack consumption. 


\section{ACKNOWLEDGE}

This work is supported by Hibah PITTA 2018 funded by DRPM Universitas Indonesia No. 5000/UN2.R3.1/HKP.05.00/2018.

\section{BIODATA}

Fitria Angeliqa has a PhD in Communication Studies, Universitas Indonesia (UI). Her interest is in research on postmodern philosophy, gender, strategic communications, and media studies. Email: fitria.angeliqa.17@gmail.com

Billy K. Sarwono is a Professor at the Department of Communication Science, Faculty of Social and Political Sciences, Universitas Indonesia (UI) in Jakarta. Her research activities are mostly related to the media, especially on women, children, or climate change issues. Email: billysarwono@gmail.com 


\section{REFERENCES}

AGB Nielsen. (2010). AGB Nielsen newsletter March 2010 Indonesia. Retrieved from http://www.nielsentam.tv/Uploads/Indonesia/AGBNielsenNewsletterMarch2010Ind.pdf

Arnett, R. C. (2007). Hannah Arendt: Dialectical communicative labor. In P. Anerson (Ed.), Perspectives on philosophy of communication (pp. 67-82). Indiana: Purdue University Press.

Badan Intelijen Negara. (2012). Jajanan berbahaya di sekitar anak. Bin.go.id. Retrieved from http://www.bin.go.id/awas/detil/132/4/11/08/2012/jajanan-berbahaya-di-sekitaranak

Baran, S. (2013). Introduction to mass communication: Media literacy and culture. New York: McGraw-Hill.

Bourdieu, P. (1980). The logic of practice. California: Stanford University Press.

. (1983). Language and symbolic power. Cambridge, Massachusetts: Harvard University Press.

. (2007). Contemporary sociological theory. USA: Blackwell Publishing.

Calhoun, C., LiPuma, E., \& Postone, M. (1993). Bourdieu: Critical perspective. Chicago: The University of Chicago Press.

Dinkes-sulsel.go.id. (n.d.). Keputusan menteri kesehatan Republik Indonesia No. 942/MENKES/SK/VII/2003 tentang pedoman persyaratan hygiene sanitasi makanan jajanan (Bab 1, Ketentuan Umum, Pasal 1). Retrieved from http://dinkessulsel.go.id/new/images/pdf/Peraturan/kmk\%20persyaratan\%20hygiene\%20sanitasi \%20makanan\%20jajan\%20942-2003.pdf

Dono, N. D. (2012). Zat berbahaya dalam makanan. KIBAR. Retrieved February 8, 2016, from http://www.kibar-uk.org/2012/03/09/zat-berbahaya-dalam-makanan/

Hawkins, D., \& Mothersbaugh, D. (2010). Consumer behavior: Building marketing strategy. New York: McGraw-Hill.

Huat, N. C. (2019). Are advertisements shaping our consciousness? An analysis of selected Chinese New Year print and TV advertisements. Jurnal Komunikasi: Malaysian Journal of Communication, 24, 34-45.

Komisi Penyiaran Indonesia. (2015). Komisi penyiaran Indonesia: Lembaga Negara Independen. Retrieved from http://kpi.go.id/download/Pengumuman/Handouthasil-survei-indeks-kualitas-program-siaran-televisi-maret-april-2015-KPI.pdf

KOMPAS. (2010, September 2). Kualitas jajanan sekolah buruk. Retreived from https://regional.kompas.com/read/2010/09/02/17081437/Kualitas.Jajanan.Sekolah. Buruk

Kress, G. (2003). Literacy in the new media age. London: Routledge.

Kristanto, P. (2012). Iklan TV merusak pola konsumsi anak. Lembaga Konsumen Yogyakarta. Retrieved from http://lembagakonsumen.org/2012/05/iklan-tv-merusak-polakonsumsi-anak-2/

Lister, M., Dovey, J., Giddings, S., Grant, I., \& Kelly, K. (2003). New media: A critical introduction (2nd ed.). New York: Routledge.

McQuail, D. (2010). Mass communication theory (6th ed.). London: SAGE Publications.

P3I. (2015). Etika pariwara Indonesia. Retrieved from http://p3i-pusat.com/wpcontent/uploads/2015/11/EPI-2014-Final-SK-Perubahan.pdf 
Persell, C. H. (1984). Understanding society: An introduction to sociology. London: Harper \& Row Publisher Inc.

Prasetya, L. A. (2010, Januari 14). Jalanan sekolah, masih ada yang mengandung zat-zat berbahaya. KOMPAS.

Retrieved

from http://regional.kompas.com/read/2010/01/14/21183786/Jajanan.Sekolah.Masih.Ad a.yang.Mengandung.Zat-zat.Berbahaya

Silverblatt, A., Miller, D. C., Smith, J., \& Brown, N. (2014). Media literacy: Keys to interpreting media messages (4th ed.). California: Praeger.

Stewart, E. W. (1981). Sociology: Human science. USA: McGraw-Hill Book Company.

Sutherland, M., \& Sylvester, A. K. (2005). Advertising and the mind of the consumer (terjemahan). Jakarta: PT Gramedia Pustaka Utama.

Triwardhani, I. J., \& Chaerowati, D. L. (2019). Interpersonal communication among parents and children in fishermen village in Cirebon Indonesia. Jurnal Komunikasi: Malaysian Journal of Communication, 35(2), 277-292.

Winarno, F., \& Allain, A. (1986). Street foods in developing countries: Lessons from Asia. FAO Regional Workshop on Street Foods in Asia. Jogjakarta, Indonesia.

Zarcadoolas, C., Pleasant, A., \& Greer, D. S. (2006). Advancing health literacy: A framework for understanding and action. USA: Jossey-Bass. 